\title{
Sex Expression and Ethylene Production in Cucumber Plants as Affected by 1-Aminocyclopropane-1- carboxylic Acid ${ }^{1}$
}

\author{
Hideyuki Takahashi and Hiroshi Suge \\ Institute for Agricultural Research, Tohoku University, Katahira, Sendai 980
}

\begin{abstract}
Summary
Ethylene production and number of pistillate flowers of cucumber plants greatly increased following the application of 1-aminocyclopropane-1-carboxylic acid (ACC), an ethylene precursor.

Ethylene evolution from discs of cucumber cotyledons varied with cultivars differring in genetic backgrounds for sex expression. The cause of such variation, however, may not probably exist in the step of conversion of ACC to ethylene.
\end{abstract}

\section{Introduction}

Evidence that ethylene is formed from 1-aminocyclopropane-1-carboxylic acid (ACC) has been presented in apple tissue (1). In cucumber plants, ethylene has been known as a sex-regulating factor; ethylene administration induces pistillate flowers $(4,7,9,11)$, while anti-ethylene agents such as $\mathrm{CO}_{2}$, $\mathrm{AgNO}_{3}$ and benzothiadiazole increase maleness $(2,3,4,14)$. Aminoethoxyvinyl glycine (AVG), which is considered to be an inhibitor of ACC biosynthesis (1), also increases the formation of staminate flowers $(2,8)$.

In addition, more ethylene was known to be produced from gynoecious strains than monoecious ones $(6,10,12)$. All these evidences indicate ethylene increases femaleness in cucumber plants.

Here, we report on the sex expression and ethylene production in cucumber plants as affected by ACC, an ethylene precursor.

\section{Materials and Methods}

Three cucumber cultivars having different genetic backgrounds for their sex expression were used.

'Matsunomidori' : Sex expression is varia-

1 Received for publication November 16, 1981. This study was presented at the Autumn Meeting of the Japanese Society for Horticultural Science, 1981. ble depending on the environmental conditions. Under low temperature-short day conditions, the number of pistillate flowers increases. Usually, the lower proximal part of the stem bears staminate flowers and the upper distal part bears pistillate flowers.

'Otone No.1': Generally, the main stem does not produce pistillate flowers, although the lateral shoots do, especially at the lower nodes.

'Higan-fushinari' : The flowers are usually pistillate.

Seeds were soaked in water overnight in an incubator at $30^{\circ} \mathrm{C}$, then sown in $7.5 \mathrm{~cm}$ plastic pots or in plastic boxes $(45 \times 35 \times 10$ $\mathrm{cm}$ ) filled with a $1: 1$ mixture of sand and vermiculite.

Experiments on sex expression were performed with potted plants in growth cabinets (Koito KG type) under 8 (SD, 9 a. m. -5 p. m.) and $24 \mathrm{~h}$ (LD) photoperiods. The light source consisted of twenty-two 80 watt fluorescent lamps (Toshiba), nine 400 watt extra high pressure mercury lamps (metalhaloid, "Yoko", Toshiba) and twelve 200 watt refractor lamps (Toshiba), providing about $15,0001 \mathrm{x}$ at the plant level. Plants were watered with Hyponex nutrient solution. Temperature for both photoperiods was $25^{\circ} \mathrm{C}$ from 9 a. m. to 5 p. m. and $20^{\circ} \mathrm{C}$ from 5 p. m. to 9 a. m.

Two cultivars, 'Matsunomidori' and 'Otone No.1', were grown in the growth cabinet 
under LD from germination for testing the effect of ACC on their sex expression. 'Matsunomidori' plants were transferred to SD condition at the 2-leaf stage and subjected to ACC treatment. Twenty $\mu l$ of $1 \mathrm{mM}$ or $0.1 \mathrm{mM}$ ACC solution was applied daily for 5 days to the shoot tip using a micropipette. 'Otone No.1' plants were grown under LD throughout the experiment. ACC was applied from the 2-leaf stage. Fourty $\mu \mathrm{l}$ of $1 \mathrm{mM}$ ACC solution were applied to the shoot tip daily for 5 days.

To examine the production of ethylene by plant tissues treated with ACC, two experiments were conducted using plants grown in boxes. 'Otone No. 1' plants grown in a greenhouse were used at the 1-leaf stage. The seedling was cut at the soil surface and the hypocotyl was inserted into $30 \mathrm{ml}$ of distilled water and enclosed in a $500 \mathrm{ml}$ capsule, designed especially for ethylene treatment and measurement (13). Sixty $\mu l$ of $1 \mathrm{mM}$ ACC solution was applied to the tip of cut plant just before enclosing it in to the capsule. The capsule has a side mouth that was fitted with a rubber stopper through which sample gas was withdrawn for ethylene determination.

For examining the difference in their abilities for the conversion of ACC to ethylene, 3 cucumber cultivars with different genetic backgrounds for their sex expression were used. Plants sown in boxes were grown in the greenhouse and harvested at their cotyledonary stage and then discs, $1.5 \mathrm{~cm}$ in diameter, were cut from the cotyledons using a corkborer. Two discs were placed in $30 \mathrm{ml}$ Erlenmyer flask containing either $2 \mathrm{ml}$ of distilled water or $0.1 \mathrm{mM}$ ACC solution. The flask was sealed with a rubber stopper through which head gas was sampled for ethylene determination.

These containers, capsules and flasks, were placed in an incubator at $25^{\circ} \mathrm{C}$ under continuous light of about 4,000lx. Ethylene concentration was determined with a gaschromatograph (Shimazu Model GC-4 CM type) equipped with activated alumina columns and a hydrogen ionization detector. Data presented are averages of 3 replica- tions.

\section{Results and Discussion}

Sex expression of 'Matsunomidori' and 'Otone No.1' plants as affected by ACC application is presented in Table 1 and Figs. 1 and 2. In both cultivars, ACC was found to increase pistillate flower formation and to reduce staminate flowering nodes. In 'Matsunomidori' plants, ACC induced pistillate flowers even on lower nodes beginning at node 3 (numbered from the base), although control plants bore the first pistillate flower at node 6 (Fig. 1). In untreated 'Otone No. 1' plants, only a few pistillate flowers were formed around nodes 13-14, whereas ACC-treated plants dramaticaly increased

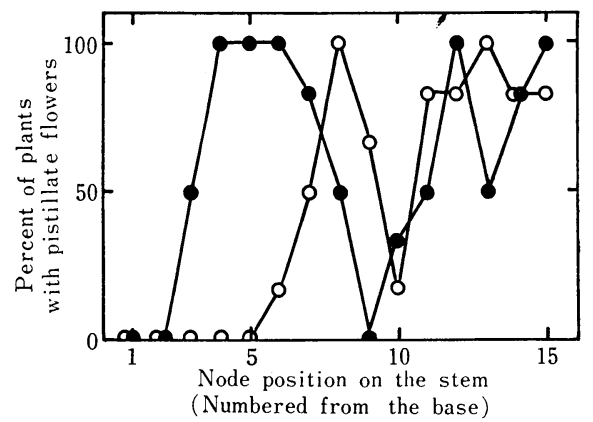

Fig. 1. Pistillate flower formation of 'Matsunomidori' cucumber plants following ACC treatment. Twenty $\mu$ l of ACC ( $1 \mathrm{mM})$ was given to the shoot tip daily for 5 days beginning at from the 2-leaf stage. Data presented are averages of 6 plants. Not treated $(O)$ and treated with $\operatorname{ACC}(\bullet)$.

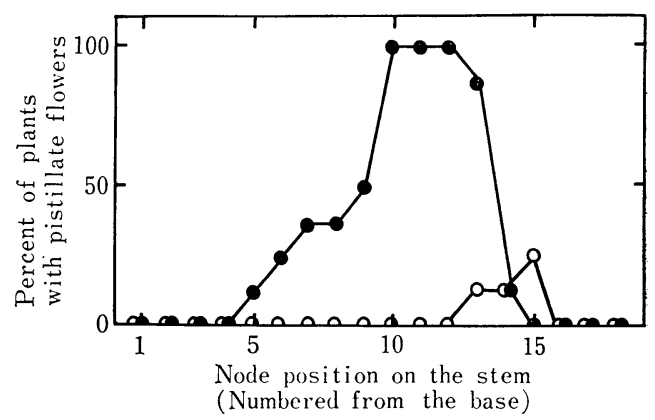

Fig. 2. Pistillate flower formation of 'Otone No.1' cucumber plants following ACC treatment. Fourty $\mu \mathrm{l}$ of ACC $(1 \mathrm{mM})$ was given to the shoot tip daily for 5 days beginning at the 2-eaf stage. Data presented are averages of 8 plants. Not treated $(O)$ and treated with ACC (•). 


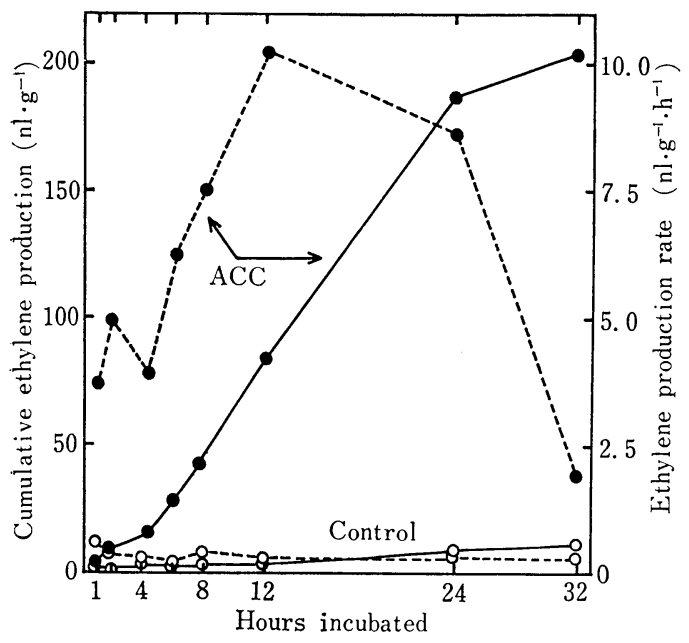

Fig 3. Influence of $\mathrm{ACC}$ on ethylene production in vegetative tissues of 'Otone No.1' cucumber plants. Shown both cumulative ethylene production (-) and ethylene production per hour $(---)$. Not treated $(O)$ and treated with ACC

(•). For details, refer to the text.

pistillate flowering nodes beginning at node 5 and almost more than 90 percent each of nodes 10-13 bore pistillate flowers (Fig. 2).

Application of $60 \mu \mathrm{l}$ of $1 \mathrm{mM}$ ACC solution. to the apical tip of 'Otone No.1' seedlings at the 1-leaf stage evoked a significant increase in ethylene production (Fig. 3), which was observed even $1 \mathrm{~h}$ after the treatment of ACC. Rapid ethylene production stimulated by ACC treatment continued for $12 \mathrm{~h}$ after the application and reduced thereafter (Fig. 3).

Ethylene production of tissues excised from

Table 1. Sex expression of 'Matsunomidori' and 'Otone No.1' cucumber plants as affected by ACC application.

\begin{tabular}{cll}
\hline & $\begin{array}{l}\text { Number of } \\
\text { staminate } \\
\text { flowering } \\
\text { nodes }^{2}\end{array}$ & $\begin{array}{l}\text { Number of } \\
\text { pistillate } \\
\text { flowering }^{\text {nodes }}\end{array}$ \\
\hline $\begin{array}{c}\text { Matsunomidori } \\
\text { Control }\end{array}$ & $5.5 \pm 0.8$ & $2.5 \pm 0.8$ \\
ACC $0.1 \mathrm{mM}$ & $3.5 \pm 0.8$ & $4.5 \pm 0.8$ \\
ACC $1 \mathrm{mM}$ & $2.3 \pm 0.5$ & $5.2 \pm 1.0$ \\
Otone No.1 & $17.5 \pm 0.5$ & $0.5 \pm 0.5$ \\
Control & $13.2 \pm 1.2$ & $5.7 \pm 1.8$ \\
ACC $1 \mathrm{mM}$ &
\end{tabular}

$z$ : Number of flowering nodes per plant up to node 10 for 'Matsunomidori' and node 18 for 'Otone No.1' on the main stem. Data presented are averages of six plants for 'Matsunomidori' and of eight plants for 'Otone No.1'. root, stem, leaf, inflorescence and fruit of 16 plant species greatly increased following the application of ACC (5). All these kinds of fruits, including cucumber, displayed a 10 to 20 fold increase in rate of ethylene production in the presence of $1 \mathrm{mM} \mathrm{ACC}$, as compared with controls (5).

Ethylene production from cucumber seedlings was also considerably increased by exogenous ACC application (Fig. 3), indicating vegetative tissues of cucumber plants also have the enzymatic system for the conversion of ACC to ethylene. Sex expression affected by ACC application in the present experiments (Figs. 1 and 2, and Table 1), therefore, might be due to the increased ethylene production that was produced from applied ACC.

Evidences indicating ethylene is a sex-regulating factor have been accumulated in cucurbits. Atsmon and Tabbak (2) found that application of AVG, an inhibitor of ACC biosynthesis (1), induced staminate flowers in gynoecious cucumber.

The effect of exogenous ACC on sex expression of cucumber plants seems almost similar to that of ethephon (2-chloroethylphosphonic acid), an ethylene-releasing agent. However, as Cameron et al. (5) stated, ACC may prove to have important uses in agriculture since it is a natural amino acid and readily converted to ethylene by plant tissues.

Rate of ethylene production in cucumber plants has been reported to vary with cultivars due to their different genetic backgrounds for sex expression $(10,12)$. Recently, Fujita and Fujieda (6) found that difference in etiolation rate among seedlings with different genotypes for sex expression corresponded to their abilities for ethylene production. Such a varietal difference in ethylene production is also shown in our results (Fig. 4).

Rate of ACC-induced ethylene production from 'Otone No. 1' cotyledon discs was much higher than that from shoot tips of the same cultivar under the present experimental conditions. This might be partly due to the rapid infiltration of $\mathrm{ACC}$ in to the cotyledon discs because of their greater area of cut 

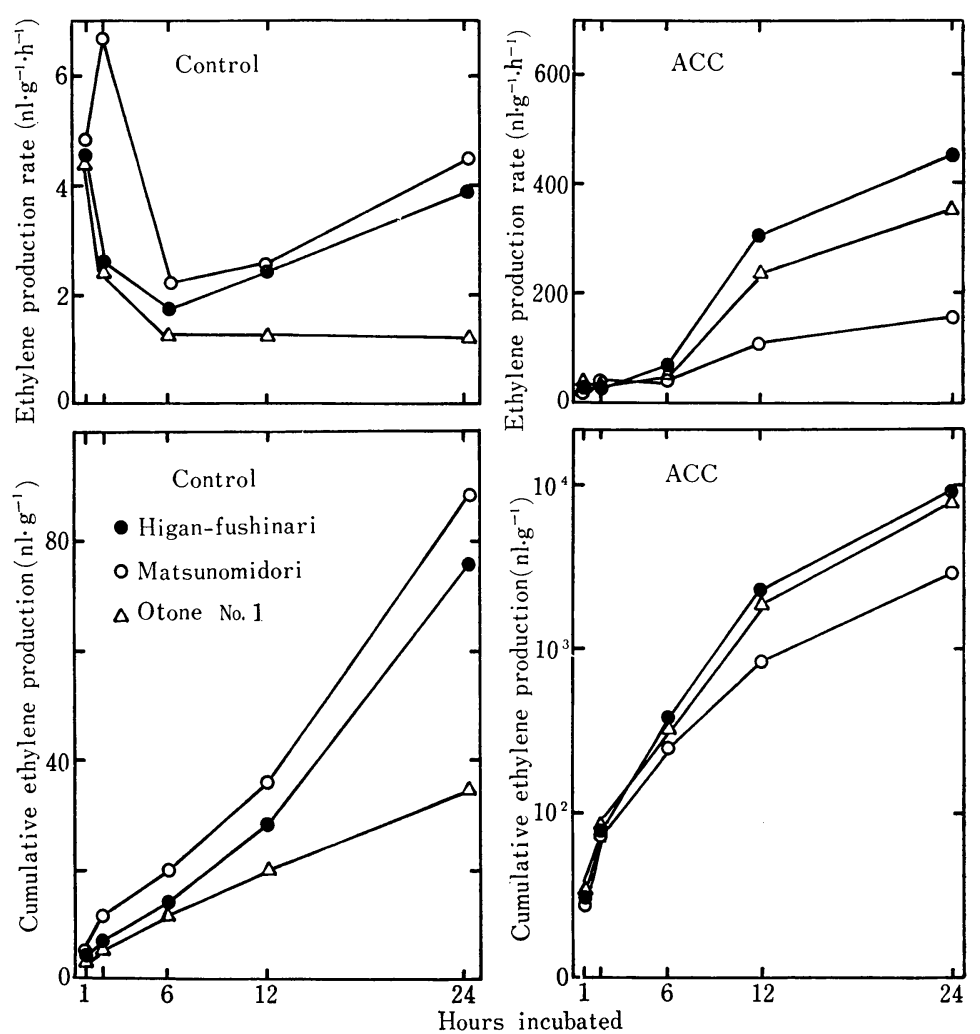

Fig. 4. Influence of ACC on ethylene production in cotyledon discs of 3 different cucumber cultivars. Shown both cumulative ethylene production (lower) and ethylene production per hour (upper). The scale for the cumulative ethylene production for ACC-treated plants in the lowerright hand is shown in logarithmic. For details, refer to the text.

surface and partly due to the difference of plant part per se from which discs were prepared.

Ethylene production from cotyledon discs floated on water was less in 'Otone No.1' than in 'Higan-fushinari' or 'Matsunomidori' plants (Fig. 4). Much more ethylene has been known to be produced in gynoecious cucumber strains than in monoecious ones $(6,10$, 12). In the presence of exogenous ACC, however, the difference in ethylene production among the 3 cucumber cultivars did not correspond to their genotypes for sex expression. These results may suggest that the difference in ethylene production among cultivars having different genetic backgrounds may not probably exist in the step of conversion of ACC to ethylene. Difference in the ability of ACC biosynthesis must be further investigated.
We wish to express our gratitude to Dr. H. Imaseki, Nagoya University, for the gift of ACC. We would also like to thank Prof. Y.Hori of Tohoku University for his advice.

\section{Literature Cited}

1. ADAMS, D. O. and S. F. YANG. 1979. Ethylene biosynthesis: Identification of 1-aminocyclopropane-1-carboxylic acid as an intermediate in the conversion of methionin to ethylene. Proc. Natl. Acad. Sci. USA 76: $170-174$.

2. A TSMON, D. and C. TABBAK. 1979. Comparative effects of gibberellin, silver nitrate and aminoethoxyvinyl glycine on sexual tendency and ethylene evolution in the cucumber plant (Cucumis sativus L. Plant \& Cell Physiol. $20: 1547-1555$.

3. BEYER, E. Jr. 1979. Silver ion: A potent antiethylene agent in cucumber and tomato. HortScience 11 : 195-196. 
4. Byers, R. E., L. R. BAKER, H. M. SMITH, R. C. HERNER, and D. R. DILlEY. 1972. Ethylene: A natural regulator of sex expression of cucumis melo L. Proc. Natl. Acad. Sci. USA $69: 717-720$.

5. CAmeron, A. C., C. A. L. Fenton, Y. YU D. O. ADAMS, and S. F. YANG. 1979. Increased production of ethylene by plant tissues treated with 1-aminocyclopropane-1-carboxylic acid. Hort-Science $14: 178-180$.

6. FujitA, Y. and K. FujIEDA. 1981. Relation between sex expression types and cotyledon etiolation of cucumber in vitro. I. On the role of ethylene evolved from seedlings. Plant \& Cell Physiol. 22 : 667-674.

7. IWAHORI, S., J. M. LYONS and O. E. SMITH. 1970. Sex expression in cucumber plants as affected by 2-chloroethylphosphonic acid, ethylene, and growth regulators. Plant Physiol. $46: 421-415$.

8. LOY, J. B., T. A. NATTI, C. D. ZACJ and S. K. FRITTS. 1979. Chemical regulation of sex expression in a gynomonoecious line of muskmelon. J. Amer. Soc. Hort. Sci. 104 :
$100-101$

9. McMurray, A.C. and C. H. Miller. 1968. Cucumber sex expression modified by 2chloroethanephosphonic acid. Science 162: 1397-1398.

10. RUdich, J., L. R. BAKER, J. W. SCOTT, and H. M. SELL. 1976. Phenotypic stability and ethylene evolution in androecious cucumber. J. Amer. Soc. Hort. Sci. $101: 48-51$.

11. Rudich, J., A. H. HALEVy, and N. KEDAR. 1969. Increase in femaleness of three cucurbits by treatment with Ethrel, an ethylene releasing compound. Planta $86: 69-76$.

12. Rudich, J., A. H. Halevy, and N. KedAR. 1972. Ethylene evolution from cucumber plants as related to sex expression. Plant Physiol. 49 : 998-999.

13. SUGE, H. 1971. Stimulation of oat and rice mesocotyl growth by ethylene. Plant \& Cell Physiol. $12: 831-837$.

14. TAKAhashi, $H$. and H. Suge. 1980. Sex expression in cucumber plants as affected by mechanical stress. Plant \& Cell Physiol. 21 : $303-310$.

\title{
エチレン前駆物質 1ーアミノシクロプロパン-1ーカルボン酸によるキュウリ \\ の性表現とエチレン生成
}

\author{
高 橋 秀 幸・菅洋 \\ 東北大学農学研究所 980 仙台市片平
}

\begin{abstract}
摘 要
キュウリの性表現について遺伝的背景の異なる品種を 用いて，その性表現とエチレン生成に及ぼすェチレンの 前駆物質 1-アミノシクロプロパン-1-カルボン酸 (ACC) の効果を調べた。

ACC 処理により，性表現について遺伝的背景の異な る 2 品種のいずれにおいても雌性化が著しく促進され た. 特に主茎上に雌花をほとんど着生しない'大利根 1 号’においてその効果が著しかった。

$\mathrm{ACC}$ は，供試したキュウリ 3 品種の子葉から得た葉

円板よりのエチレン生成を著しく促進し，その量は対照 区の約 100 倍にも達した. ACCによるエチレン生成の 促進は, 幼植物の茎頂部に処理した場合にも同様に認め られた。

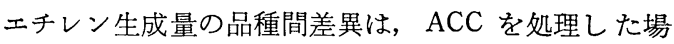
合と，処理しなかった場合とで一致しなかった。 したが って, 性表現の異なる品種間のエチレン生成能の差異 は, ACC からのエチレン生成の段階より以前の段階に 起因すると思われる.
\end{abstract}

